\title{
Inflorescence and floral traits of the Colombian species of Tristerix (Loranthaceae) related to hummingbird pollination
}

\author{
Favio González ${ }^{1, *}$ \& Natalia Pabón-Mora ${ }^{2}$ \\ ${ }^{1}$ Facultad de Ciencias, Instituto de Ciencias Naturales, Universidad Nacional de Colombia, AA 7495 Bogotá, Colombia \\ ${ }^{2}$ Instituto de Biología, Universidad de Antioquia, AA 1226 Medellín, Colombia \\ ${ }^{*}$ Corresponding author: fagonzalezg@unal.edu.co, http://orcid.org/0000-0001-5716-9278 \\ ${ }^{2}$ lucia.pabon@udea.edu.co, http://orcid.org/0000-0003-3528-8078
}

\begin{abstract}
Floral diversification in Loranthaceae reaches its highest peak in the Andes. The flowers of the exclusively Andean genus Tristerix exhibit tubular and vividly coloured flowers pollinated by hummingbirds. We studied inflorescence and flower morphoanatomy of the two Colombian species, T. longebracteatus and the highly endangered T. secundus. Both species have terminal racemes with up to 26 ebracteolate flowers, of which the proximal one opens and sets fruits first. The slightly irregular calyx initiation is followed by the simultaneous initiation of petals and the successive initiation of stamens. Anthesis is fenestrate, explosive, and triggered by the tension of the style against the abaxial petals, a mode so far not reported in Loranthaceae. Anthetic petals spread symmetrically in T. longebracteatus and asymmetrically in T. secundus. Nectar is produced by a supraovarial disk and by the petal mesophyll. Floral lifespan lasts up to 20 days. The hummingbirds Eriocnemis vestita and Pterophanes cyanopterus are the likely pollinators of $T$. secundus. Morphological traits are inconclusive to support one of the two competing sister group relationships that involve Tristerix, as the lack of cataphylls in renewal shoots links Ligaria and Tristerix, whereas the terminal inflorescences support its relationship with Desmaria and Tupeia.
\end{abstract}

Keywords. Explosive anthesis, fenestrate anthesis, flower development, flower morphoanatomy, inflorescence development, ornithophily syndrome, páramo mistletoes, Santalales.
Resumen. La diversificación floral en Loranthaceae alcanza su máxima expresión en los Andes. Las flores del género Tristerix, restringido exclusivamente a dicha cordillera, exhiben flores tubulares y de color llamativo que son polinizadas por colibríes. Se ha realizado un estudio de la morfoanatomía de inflorescencias y flores en las dos especies colombianas del género, T. longebracteatus y T. secundus, esta última muy amenazada. Las dos especies tienen racimos terminales hasta con 26 flores ebracteoladas, de las cuales la proximal se abre y forma el fruto antes que las demás. La iniciación del cáliz, levemente irregular, es seguida por la iniciación simultánea de los pétalos y la iniciación sucesiva de los estambres. La antesis es fenestrada, explosiva y se activa por la tensión del estilo contra la comisura de los dos pétalos abaxiales, un modo de antesis hasta ahora no descubierta en Loranthaceae. Los pétalos en antesis se expanden simétricamente en T. longebracteatus y asimétricamente en $T$. secundus. El néctar se produce en un disco supraovárico y el mesófilo de los pétalos. El periodo entre la antesis y la iniciación del fruto dura hasta 20 días. Las especies de colibrí Eriocnemis vestita y Pterophanes cyanopterus son los visitantes y probables polinizadores de T. secundus. Los rasgos morfológicos de Tristerix no aportan información concluyente para apoyar una de las dos hipótesis relacionadas con los posibles grupos hermanos del género, ya que la ausencia de catafilos en los brotes de renuevo asocian Ligaria y Tristerix, en tanto que las inflorescencias terminales apoyan una relación cercana a Desmaria y Tupeia.

Palabras clave. Antesis explosiva, antesis fenestrada, desarrollo floral, desarrollo de inflorescencias, morfoanatomía floral, muérdagos de páramo, Santalales, síndrome de ornitofilia.

González F. \& Pabón-Mora N. 2017. Inflorescence and fl oral traits of the Colombian species of Tristerix (Loranthaceae) related to hummingbird pollination. Anales Jard. Bot. Madrid 74 (2): e061. http://dx.doi.org/10.3989/ajbm.2474

Title in Spanish: Caracteres de la inflorescencia y las flores de las especies colombianas de Tristerix (Loranthaceae) relacionados con la polinización por colibríes.

Received: 15-III-2017; accepted: 25-VI-2017; published online: 03-XI-2017; Associate Editor: J. Fuertes.

\section{INTRODUCTION}

The morphological diversification of flowers in Loranthaceae reaches its highest peak in the Andes. However, most of the studies on inflorescence and flower morphoanatomy and reproductive biology have been carried out in Old World members of the family (v.gr., Blakely 1922; Maheshwari \& al. 1957; Bhatnagar \& Johri 1983; Feehan 1985; Ladley \& al. 1997). Thus, the inflorescence and floral traits related to pollination remain to be investigated in neotropical taxa, including Tristerix Mart., a genus that comprises 12 species confined to high elevations in the Andes from Colombia to Chile (Barlow \& Wiens 1973; Kuijt 1988, 2015).

The species of Tristerix exhibit long, tubular, and vividly coloured flowers that are pollinated by hummingbirds (Reiche 1904; Tadey \& Aizen 2001; Aizen 2005; Amico \& al. 2007). Two species in Colombia mark the northernmost distribution of the genus, T. longebracteatus (Desr.) Barlow \& Wiens and T. secundus (Benth.) Kuijt. The distribution of these two species in Colombia is disjunct, as T. longebracteatus grows in the Central Cordillera, whereas T. secundus is endemic to the Eastern Cordillera. Together 
with Aetanthus (Eichl.) Engl. and Gaiadendron G.Don, these are the only Loranthaceae that reach the páramos in Colombia. Tristerix longebracteatus and T. secundus grow between 2,900 and 3,900 $\mathrm{m}$ a.s.l. The habitats occupied by these species are increasingly threatened by agricultural expansion and strong disturbance. In particular, the current conservation status of $T$. secundus deserves special attention because this species is known to occur only in a few páramos of the departments of Boyacá, Cundinamarca, and Meta, near densely populated areas. The goal of the present research is to investigate the so far overlooked morphoanatomical traits of inflorescences and flowers of the páramo species of Tristerix that are supposedly pollinated by hummingbirds.

\section{MATERIAL AND METHODS}

Tristerix longebracteatus was collected in the Central Cordillera - Colombia, Department of Caldas, Manizales, ascenso al PNN Los Nevados, sector Brisas-Termales, 3,450-3,650 m a.s.1., 21 May 2007, F. González \& al. 4270, fl., fr. (COL) - Tristerix secundus was collected in the Eastern Cordillera - Colombia, Cundinamarca, Tausa, high-andean forest near páramo de Guerrero, 3,420 m a.s.l., 18 Dec. 2014, F. González \& al. 4567, fl., fr. (COL)—. The terminology followed here is based on Suaza-Gaviria \& al. $(2016,2017)$; the terms adaxial and abaxial are used in reference to the axis of the inflorescence.

Macromorphological measurements, counts, and general observations were made in the field, avoiding invasive methods that would damage the small populations. We collected a limited number of flowers and inflorescences, as these plants are very scarce in their habitats. Nevertheless we took abundant photographic material that was used for counts and observations, which included no less than 40 inflorescences in different developmental stages with an average of 20 floral buds of mature flowers per inflorescence.

For anatomical studies flowers in several developmental stages were fixed in $70 \% \mathrm{EtOH}$. Buds were dissected in 90\% EtOH under a Leica MZ7.5 stereomicroscope — Leica Microsystems, Heerbrugg, Switzerland- and dehydrated in an absolute ethanol series $-90 \%, 95 \%$, to $100 \% \times 2$ ethanol, 30 min each-. Fixed material was dehydrated through an alcohol-Histochoice series, and embedded in Paraplast X-tra -Fisher Healthcare, Houston, Texas, USA - The samples were sectioned at $12 \mu \mathrm{m}$ with an AO Spencer 820 - GMI Inc. Minnesota, US - rotary microtome. Sections were stained with Johansen's safranin and $0.5 \%$ Astra Blue, and mounted in Permount - Fisher Scientific, Pittsburgh, Pennsylvania, USA-. Sections were viewed and digitally photographed with a Nikon Eclipse 80i compound microscope equipped with a Nikon DXM1200C digital camera with ACT (1) software.

\section{RESULTS}

In general, the morphoanatomical and developmental traits of the two examined species are very similar. Thus, we describe the results simultaneously for both species, except for those characters that vary among them or that were preferentially recorded for $T$. secundus in the field.

\section{Inflorescence development and morphology}

Individuals in both species are stem hemiparasites with a slightly thickened primary haustorium and no epicortical roots. They copiously ramify from early stages soon after seedling establishment (fig. 1a). Up to three individuals of T. longebracteatus were observed parasitizing a single tree of Escallonia myrtilloides L.f. -Escalloniaceae R.Br. ex Dumort.- whereas up to five individuals of $T$. secundus were observed growing in a single shrub of Ageratina baccharoides (Kunth) R.M.King \& H.Rob. - Asteraceae Bercht. \& J.Presl-. Young branches are dull reddish but they turn dull green to dark gray when flowering (fig. 1a, f, g). Branching is sympodial as inflorescences are terminal and the two axillary shoots immediately below the inflorescence successively develop into renewal shoots (figs. 1b, d, e, h, 2b, 3a-c). Shoots in both species reach up to $1 \mathrm{~m}$ in length and have opposite, decussate leaves (fig. 1a, c, f); young stems are terete in T. longebracteatus and quadrangular in T. secundus (fig. 1j). Young inflorescences are tightly protected by the distalmost pairs of opposite leaves (fig. 1c). They develop into a raceme whose apical meristem depletes after forming up to 20 and 26 lateral flowers in T. longebracteatus and T. secundus, respectively (figs. 1b-j, 3a-c). Each flower is subtended by a single bract that is recaulescent to the pedicel (fig. 1d, e, h-j). The free portion of the bract is scale-like, ovate, to $4 \times 3.5 \mathrm{~mm}$ and tightly appressed to the pedicel (fig. 1b-i) in T. secundus, whereas it is leafy, narrowly lanceolate, to $3.5 \times 1.8 \mathrm{~cm}$ (fig. $1 \mathrm{j}$ ) in T. longebracteatus.

Flower initiation proceeds acropetally along five ontogenetic spiral lines (fig. 1b, c, 2a, b), but mature inflorescences appear to have flowers arranged in whorls (fig. 1e, h, i). When the young flowers reach $5 \mathrm{~cm}$ in length, the entire inflorescence becomes pendant (fig. 1f, j). Immediately before anthesis, flowers of $T$. secundus are lifted to a nearly horizontal orientation due to the strong increase in pedicel thickness and a sharp angle formed between the pedicel and the flower (figs. 1h, 3a, b). The first anthetic flower - hereafter called the leading floweris always placed in an upper position as it corresponds to the proximal flower of the pendant raceme (figs. 1d, e, h, $3 \mathrm{a}-\mathrm{c})$. Anthesis proceeds downwards and young fruits are found on the upper portion of the inflorescence while lower flowers are still in preanthesis or anthesis (fig. 1g, 3a-c). 

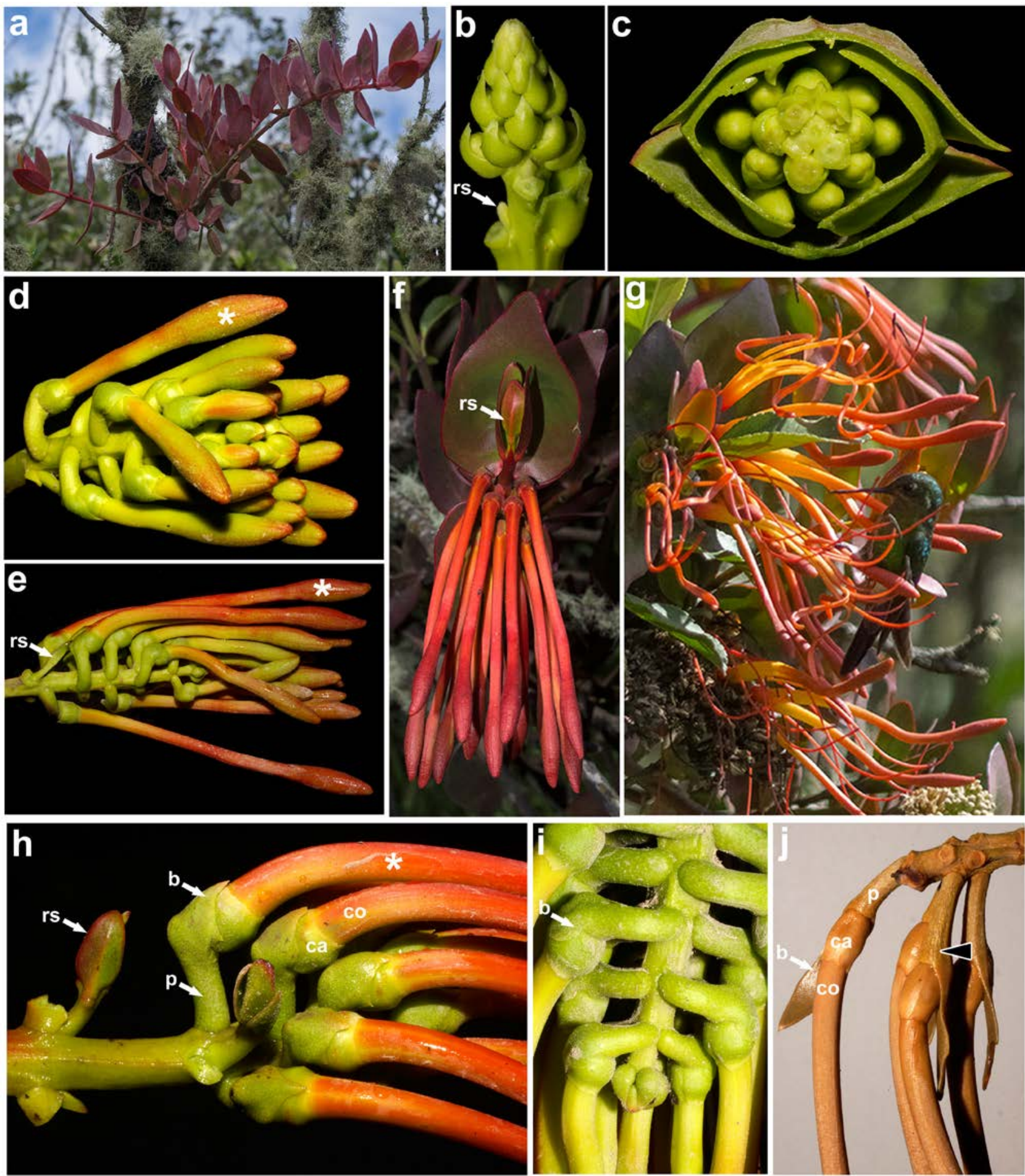

Fig. 1. Tristerix secundus (Benth.) Kuijt: a, young individual; b-f, successive developmental stages of terminal racemes; $\mathbf{g}$, Eriocnemis vestita ( $\widehat{(}^{\text {) }}$ perching on T. secundus; $\mathbf{h}$, $\mathbf{i}$, detail of inflorescence axis, bracts, and pedicels - note (in $\mathrm{H}$ ) two renewal lateral shoots- Tristerix longebracteatus (Desr.) Barlow \& Wiens: $\mathbf{j}$, detail of bracts and base of flower - note recaulescence of bract and pedicel (arrowhead) - . [Asterisks $\left({ }^{*}\right)$ indicate the leading flowers; b, bract; ca, calyx; co, corolla; p, pedicel; rs, renewal shoot.] 

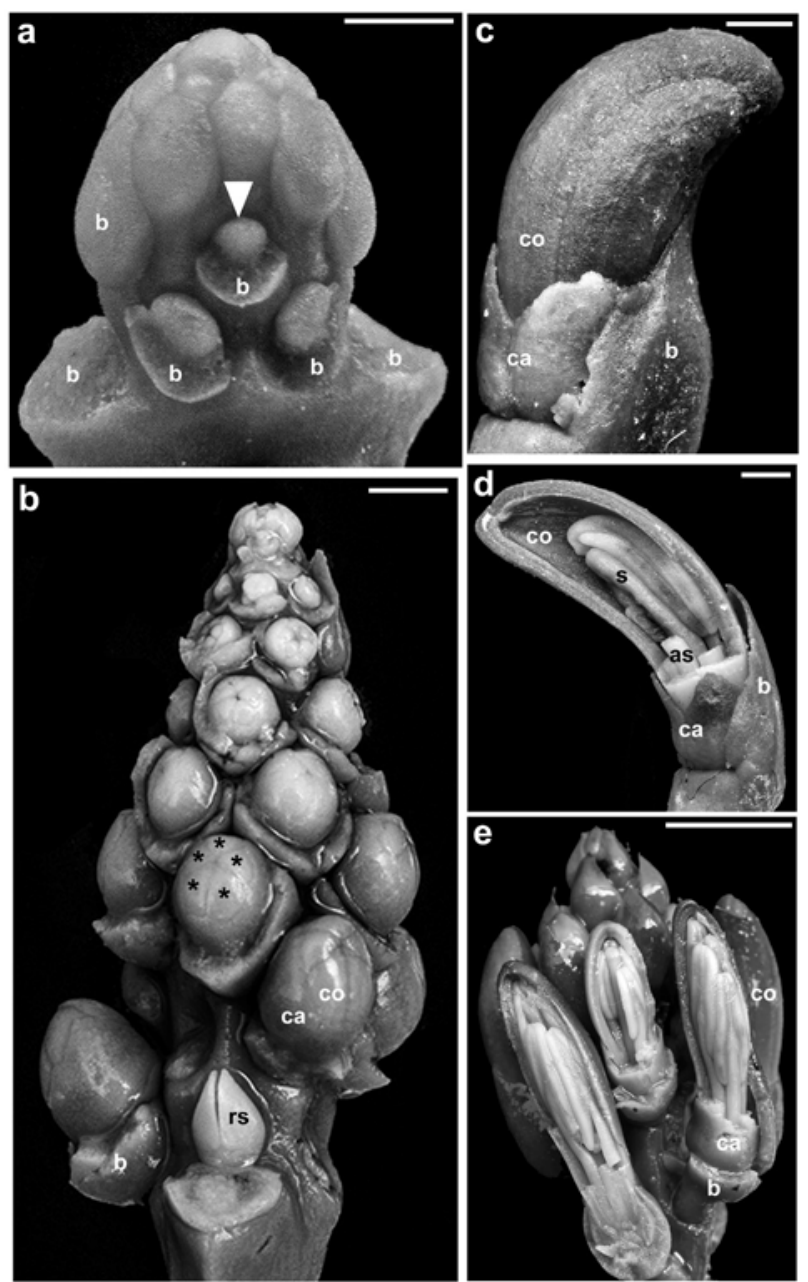

Fig. 2. Inflorescence and floral development of Tristerix secundus (Benth.) Kuijt: a, apex of inflorescence - note the radial floral primordium (arrowhead) -; b, detail of inflorescence apex showing the five spirally arranged ontogenetic lines, the successive initiation of calyx and corolla, and a renewal shoot below the raceme - asterisks indicate free petals, most subtending bracts have been removed-; c, d, successive stages of floral elongation - note early inversion of corolla curvature-; e, elongating inflorescence - some petals removed to show unequal stamens - - . [as, adaxial stamen; b, bract; ca, calyx; co, corolla; rs, renewal shoot; s, style. Scale bars: $a=500$ $\mu \mathrm{m} ; \mathrm{b}=1 \mathrm{~mm} ; \mathrm{c}, \mathrm{d}=2 \mathrm{~mm} ; \mathrm{e}=5 \mathrm{~mm}$.]

\section{Flower development and morphoanatomy}

The floral primordia are radial (fig. 2a, b). Floral organogenesis proceeds centripetally; the calyx initiates as a ring meristem above which five slightly irregular lobes are apparent but remain poorly differentiated throughout development (fig. 2b). Then, five free petals initiate alternating the sepal tips (fig. 2b). When the flower bud reaches $2.5 \mathrm{~mm}$ in diameter, the calyx encloses almost completely the petal primordia (fig. 2b), and five stamen primordia become evident opposite and slightly adnate to each petal. The adaxial stamen initiates first, followed by the initiation of the two lateral and, then, the two abaxial stamens; this sequence coincides to the three length categories in the stamens throughout development, that is, the adaxial stamen is the longest, the two lateral stamens are intermediate size, and the two abaxial stamens are the shortest (figs. 2d, e, 4b-d). The length of the coherent zone between petals and filaments reaches $2.5 \mathrm{~cm}$ in length in T. longebracteatus and $5 \mathrm{~cm}$ in T. secundus.

The corolla aestivation is valvate (figs. $2 \mathrm{~b}, 3 \mathrm{~d}-\mathrm{g}, 4 \mathrm{a}, \mathrm{j}, \mathrm{k}$, $5 \mathrm{~g}, 1)$. Young — $<1 \mathrm{~cm}$ long — corolla tubes of $T$. secundus undergo a stronger elongation of the adaxial petal, causing a c-shape curvature towards the subtending bract (fig. 2c), but soon the faster elongation of the two abaxial petals shifts the curvature away from the subtending bract (fig. 2d). No early curvatures were observed in young flowers of $T$. longebracteatus. The elongation of the five petals is accompanied by the gradual interlocking of their margins and the postgenital fusion between the base of each petal and the opposite filament (figs. 2c-e, 4j). Corolla tubes less than $2.5 \mathrm{~cm}$ long are light green but they gradually turn bright scarlet at their proximal and distal ends, and yellow at their middle portion (figs. 1d-h, 3). The fully elongated tube prior to anthesis reaches up to $5.5 \mathrm{~cm}$ in length and $7 \mathrm{~mm}$ in diameter in T. longebracteatus, and $11 \mathrm{~cm}$ in length and $9 \mathrm{~mm}$ in diameter in T. secundus. The tube is nearly straight in T. longebracteatus (fig. 4f), whereas in $T$. secundus it is slightly s-shape with its distal portion corresponding to the anther zone slightly swollen, twisted and oriented more or less upwards (figs. 3b-g, 4ae). The filaments of $T$. secundus have a small subterminal gland (fig. 4d, g), whereas those of T. longebracteatus have minute, retrorse epidermal teeth (fig. 4h). The anthers are incumbent, versatile and dorsifixed (fig. 4b-d, $\mathrm{g}, \mathrm{h}$ ). They are yellow, straight and reach up to $8.5 \mathrm{~mm}$ in T. longebracteatus (fig. $4 \mathrm{f}, \mathrm{h}$ ), whereas they are purple, slightly crescent-shape and reach up to $1.5 \mathrm{~cm}$ in length in T. secundus (fig. $4 \mathrm{~b}-\mathrm{d}, \mathrm{g}$ ).

The gynoecium is formed by five congenitally fused carpels, which are evident by the five vascular bundles and the edges alternating the petals and stamens (fig. 5b). No locules were observed at any developmental stage. By full anthesis, the solid ovary is obovoid and reaches $6-8 \times$ 5-6 mm. Nectar in both species is produced in a slightly 5-lobed supraovarial nectary ring (fig. 5j-m). Additionally, nectar production was also detected in the mesophyll of the petals in T. secundus (fig. 4k, 1). The club-shaped style is initially yellow and straight but it turns bright scarlet and slightly sinuous due to the mechanical constraint of the interlocked petals (figs. 3d-g, 4b, d, 5a, n). The style is persistent until the first stages of fruit growth (fig. 5n). The stigma is entire and slightly capitate (figs. $4 \mathrm{~b}, \mathrm{~d}, 5 \mathrm{i}$ ). The mature fruit is a globose berry to $1 \mathrm{~cm}$ in diameter, and 

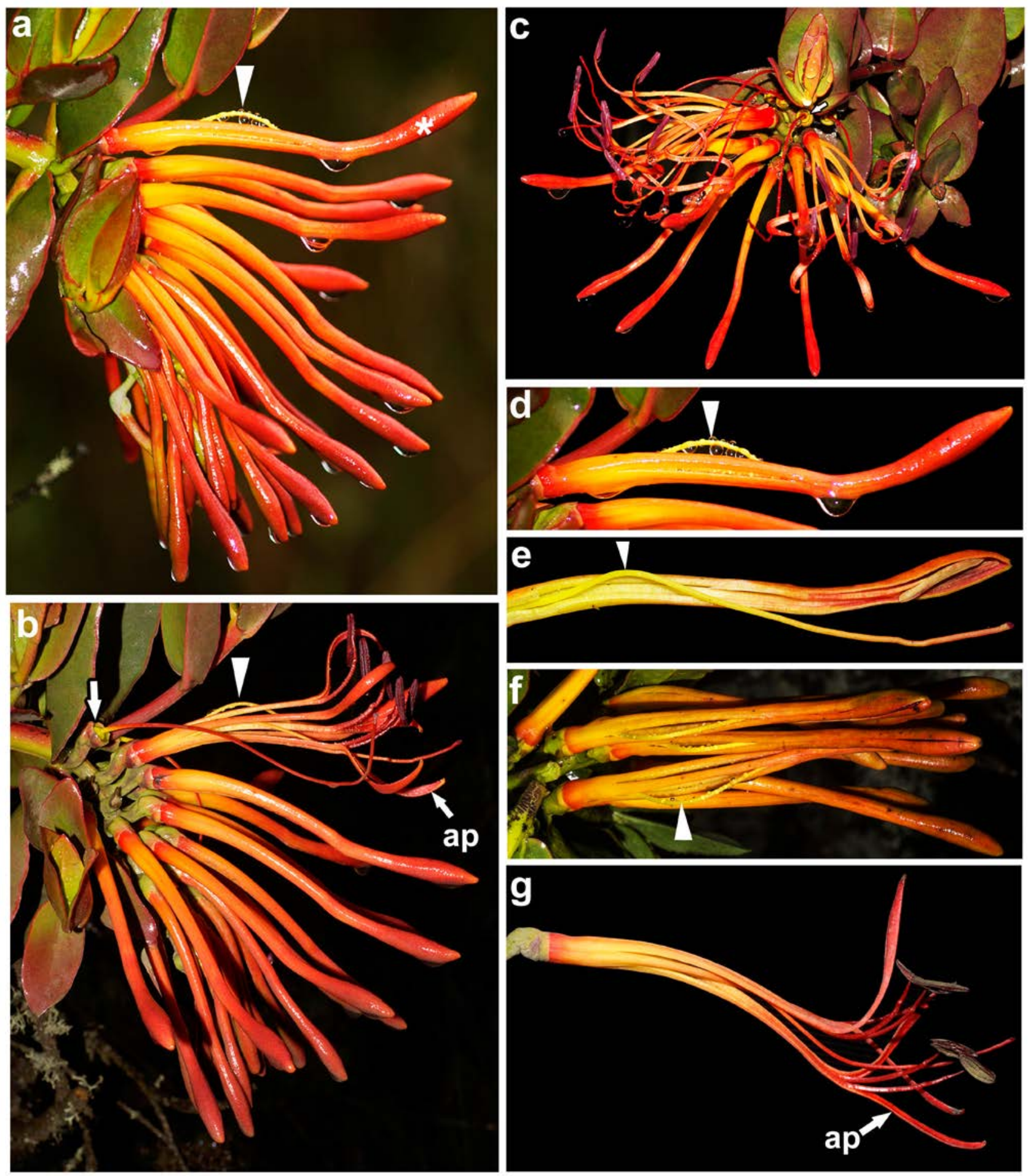

Fig. 3. Anthesis and floral lifespan of Tristerix secundus (Benth.) Kuijt: a, b, lateral views of an inflorescence photographed in a two-week interval, from the beginning of style protrusion in the leading flower to fruit set —arrow—; c, frontal view of the inflorescence - note young fruit (arrow) formed from the leading flower-; d-f, fenestrate, explosive corolla opening, lateral (D, E) and top (F) views; $\mathbf{g}$, fully opened flower. [Drops in a and d correspond to raindrops; arrowheads point to styles protruding between the abaxial petals; ap, adaxial petal.] 

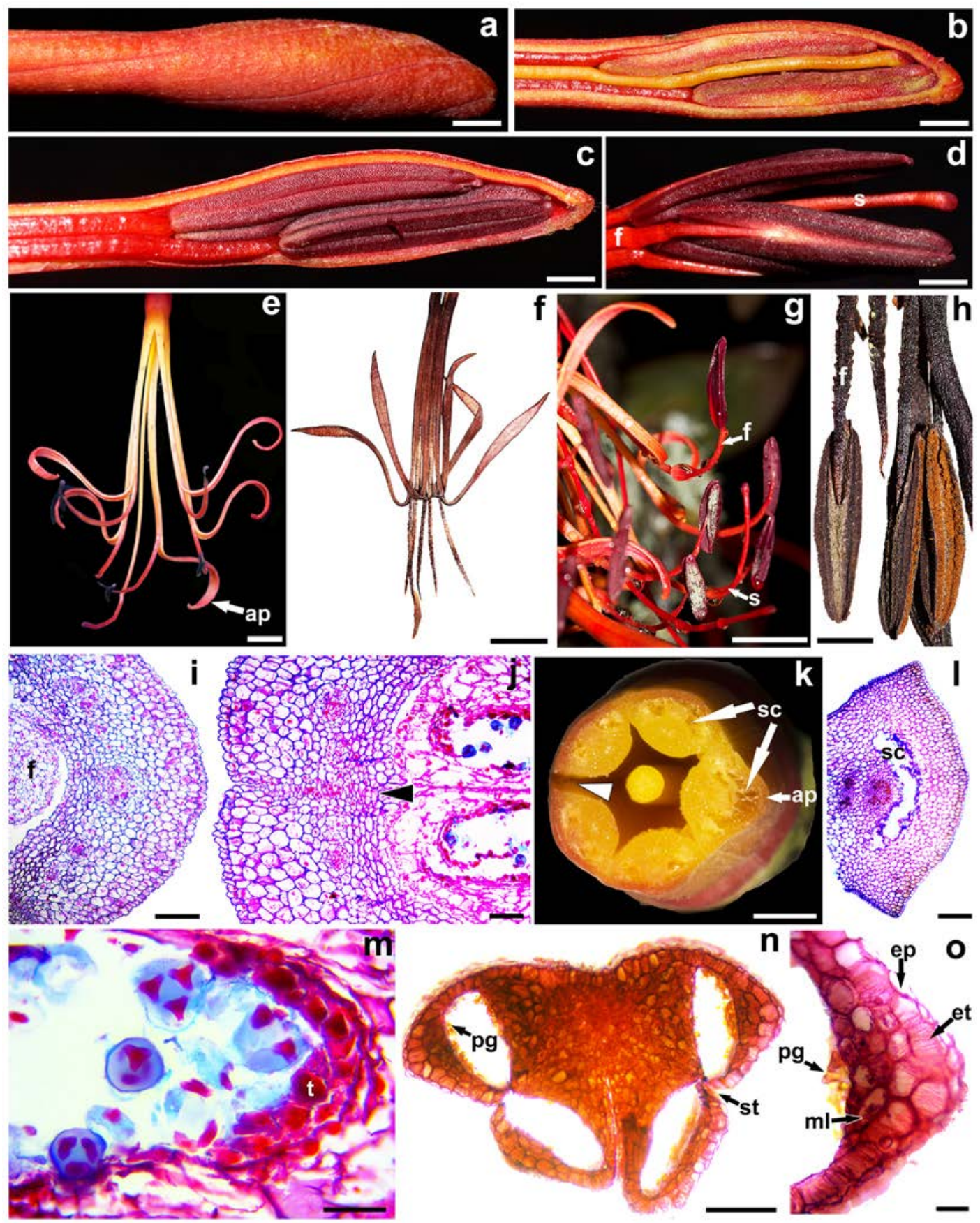

Fig. 4. Perianth and stamen morphoanatomy: a, outer details of corolla tube apex of Tristerix secundus (Benth.) Kuijt; b, c, inner details of corolla tube apex of T. secundus; d, detail of anthers, style, and stigma of T. secundus; e, anthetic flowers of T. secundus (top view); f, anthetic flower of T. longebracteatus (Desr.) Barlow \& Wiens (lateral view); g, filaments and anthers of T. secundus at in situ position; $\mathbf{h}$, filaments and anthers of T. longebracteatus at in situ position; $\mathbf{i}$, young petal of $T$. secundus, transverse section; $\mathbf{j}$, interlocking abaxial petal margins (arrowhead) of T. secundus corresponding to the fenestra, transverse section; $\mathbf{k}$, floral tube and style of T. secundus, transverse section — note the future fenestra (arrowhead) opposite the adaxial petal-; l, adaxial petal of $T$. secundus with schizogenous cavity, transverse section — note the heavy stain in the cavity border indicating secretory activity-; m, tapetum and tetrads of T. secundus; $\mathbf{n}$, tetralocular anther of $T$. longebracteatus, transverse section; o, detail of anther wall of T. longebracteatus, transverse section. [ap, adaxial petal; ep, epidermis; et, endothecium; f, filament; ml, middle layers; pg, pollen grains; s, style; sc, schizogenous cavity; st, stomium; t, tapetum. Scale bars: a-d, h, k=2 mm; e, g= $1 \mathrm{~cm} ; \mathrm{f}=5 \mathrm{~mm} ; \mathrm{i}, 1, \mathrm{n}=500 \mu \mathrm{m} ; \mathrm{j}, \mathrm{m}$, $\mathrm{o}=100 \mu \mathrm{m}$.] 

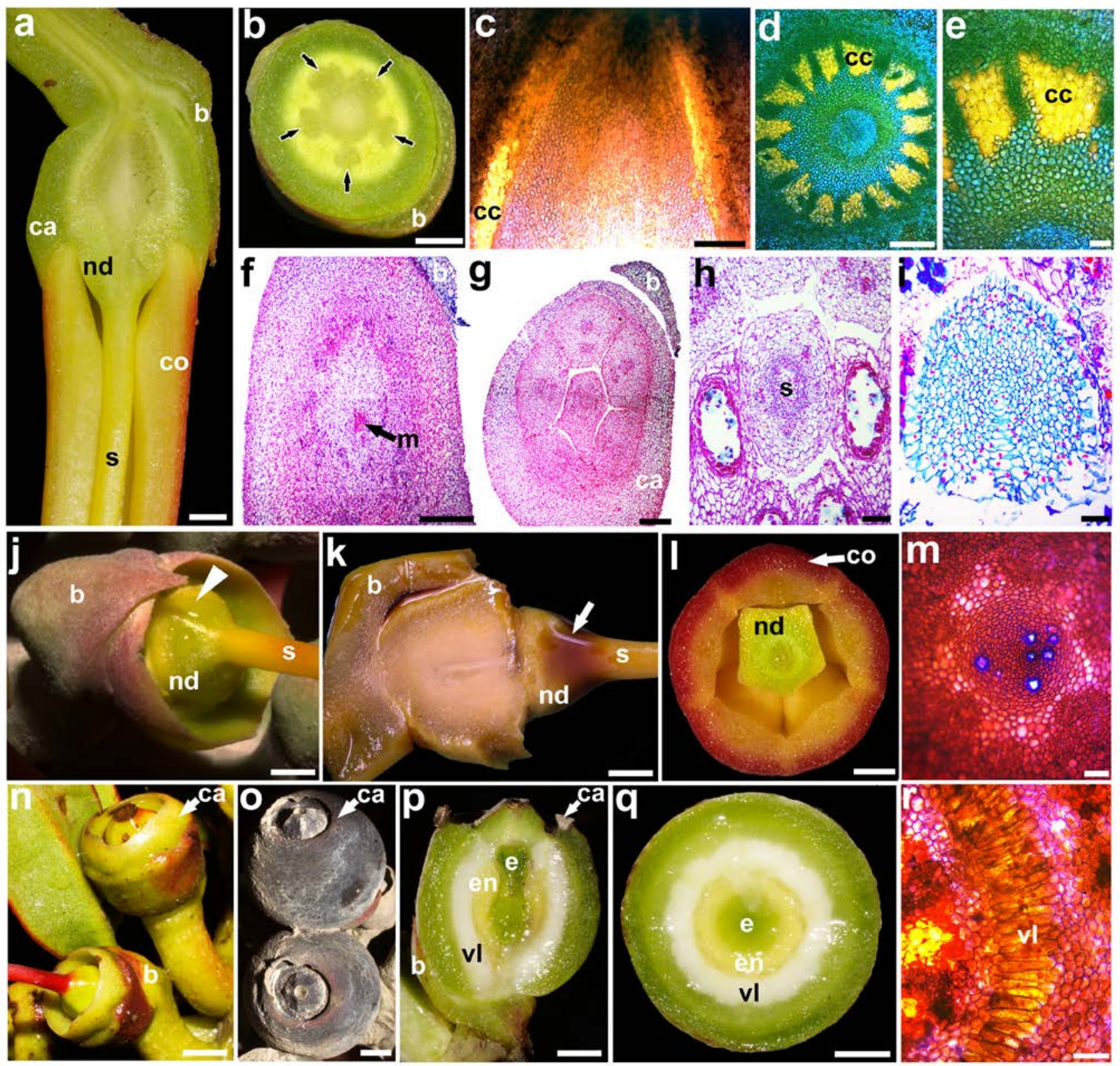

Fig. 5. Gynoecium and fruit morphoanatomy: a, longitudinal section of ovary of Tristerix secundus (Benth.) Kuijt; b, transverse section of ovary of T. secundus — arrows point to vascular bundles-; c, longitudinal section of ovary base of T. secundus — note the collenchyma cap —; d, transverse section of ovary base of T. secundus — note the collenchyma cap-; e, detail of the transverse section of ovary base of T. secundus; f, ovary and mamelon of T. longebracteatus (Desr.) Barlow \& Wiens, transverse section; $\mathbf{g}$, floral base of $T$. longebracteatus, transverse section; $\mathbf{h}$, transverse section of style of T. longebracteatus; i, transverse section of stigma of $T$. longebracteatus; $\mathbf{j}$, supraovary nectary disk of $T$. secundus, lateral view — note nectary drops (arrowhead) — ; k, supraovary nectary disk of T. secundus, longitudinal section — positive KI staining (arrow) - ; l, supraovary nectary disk of T. secundus, transverse section; m, free-hand transverse section of nectary disk of T. secundus stained with KI; $\mathbf{n}$, young fruits of T. secundus; $\mathbf{0}$, mature fruits of T. secundus; $\mathbf{p}$, longitudinal section of young fruit of T. secundus; $\mathbf{q}$, transverse section of young fruit of T. secundus; $\mathbf{r}$, detail of viscin layer in T. secundus. [b, bract; ca, calyx; cc, collenchyma cap; co, corolla; e, embryo; en, endosperm; m, mamelon; nd, nectary disk; s, style; vl, viscin layer. Scale bars: a, b, j, k, l=2 mm; c, d, f, g=500 $\mu \mathrm{m}$; e, h, i, m, r = $100 \mu \mathrm{m} ; \mathrm{n}, \mathrm{q}=3 \mathrm{~mm}$.] 
it is enclosed and fused to the calyx except by its apical portion that remains free (fig. 5n, o). The colour of the outer surface of the calyx in mature fruits gradually shifts from dull green to deep purple (fig. $5 \mathrm{n}, \mathrm{o}$ ).

\section{Floral anatomy}

Five vascular bundles enter the base of the pedicel (fig. 5b), above which they radially split into an outer ring of five traces that irrigate the common petal-stamen bases, and an inner ring that serves the gynoecium (fig. 5b). No vasculature was observed irrigating the calyx. The free portion of the mature calyx has a single epidermal layer formed by small, cuboidal, isodiametric cells. No stomata were observed. The calyx mesophyll is formed by c. 10 layers of parenchymatous cells poorly differentiated from the pericarp (fig. 5c-f). The collenchyma cap, distally formed by up to 15 bundles, lays between the pericarp and the endosperm (fig. 5c-e).

The petal epidermis adaxially and abaxially is formed by a single layer of small, slightly tangentially elongate, papillose cells (fig. 4i, j, 1); the epidermal cells of adjacent petal margins are tightly interlocked and have a thicker cuticle (fig. 4j). No stomata were observed. The vascular trace that enters the common petal-stamen base splits radially at the base of the corolla tube into a petal trace and a stamen trace (fig. $5 \mathrm{~g}$ ). Each petal is irrigated by one central trace and two pairs of lateral traces (fig. 4i, l). The petal mesophyll is formed by eight layers of isodiametric cells on the outside of the vascular traces and five layers of smaller cells on the inside (fig. 4j); the mesophyll immediately outside of the central vascular bundle is schizogenous and one or more cavities are formed (fig. $4 \mathrm{k}$, 1). The cavity in the adaxial petal is considerable larger than those formed in the remaining petals (fig. 4k). These cavities appear to be nectariferous (fig. 41).

Each stamen is served by a single vascular bundle (fig. 5g). Some epidermal outgrowths that point backwards are scattered along the distal half of the filaments of $T$. longebracteatus (fig. 4h). Anthers are dithecal, tetrasporangiate and dehisce latrorsely through a longitudinal slit (fig. 4b-e, g, n). The anther wall is formed by a narrow layer of tangentially elongated epidermal cells, a thick, fibrous endothecium that proliferates into two layers on the outer edges of the anther, one or two middle layers and an unistratified or bistratified secretory tapetum that is degraded by late preanthesis (fig. $4 \mathrm{~m}-\mathrm{o}$ ). The two pollen sacs of each theca connect to each other and open through a common latrorse stomium (fig. 4n). The microsporogenesis appears to be successive, although a few tetragonal tetrads were observed along with the predominant tetrahedral tetrads (figs. $4 \mathrm{j}, 5 \mathrm{~h}$ ). The pollen grains in both species are isopolar, tricolpate, and radially symmetrically trilobed (fig. 4n, o), a shape that becomes evident even before the reabsorption of the callose sheath of the tetrads (fig. $4 \mathrm{j}, \mathrm{m}$, 5h). Pollen is yellow in T. longebracteatus and gray to dull green in T. secundus (fig. $3 \mathrm{~h}, 4 \mathrm{~g}, \mathrm{~h}$ ).

The ovary is solid and served by a poorly differentiated vascular ring around the single mamelon (fig. 5f). The style is solid and its mesophyll is formed mainly by isodiametric cells; the cells of the central mesophyll are amyliferous and surround five poorly defined vascular traces (fig. 5h). The stigma is also solid and undifferentiated except for the short papillose epidermal cells; the mesophyll is formed mainly by isodiametric cells except for a strip of tangentially elongated cells located towards one side of the stigma (fig. 5i).

During the ovary-fruit transition (fig. 5n), a continuous viscin layer formed by radially elongated cells arranged into a palisade-like parenchyma is evident (fig. 5p-r). Mature fruits are covered by a leathery outer epidermis and a fleshy mesophyll derived from the calyx. The fruit proper is formed by a fleshy pericarp, a collenchyma cap, and a massive viscin layer (fig. 5n-r). The seeds are differentiated into a cup-shaped endosperm, which is formed between the viscin layer and the cylindrical embryo with two fused cotyledons (fig. 5p, q).

\section{Anthesis, floral lifespan, and floral visitors}

Anthesis in $T$. secundus was fully recorded in the field. The elongating style gradually bends at its midlevel producing an outward tension against the commissure of the two abaxial petals triggering a premature split of a fenestra; the bending style protrudes through the fenestra (fig. 3a-f). By that time, the corolla tube is fully s-shaped curved (fig. 3a-f). Anthesis proceeds with the explosive opening of the twisted corolla tip, exposing the bright scarlet petals, filaments, style and stigma and deep purple anthers (figs. 3f, g, 4a). The filaments spread and bend upwards lifting the dorsifixed, versatile anthers, which dehisce and release the pollen 24 to $48 \mathrm{~h}$ after anthesis; the style — slightly longer than the stamens - is also bend upwards and occupies a more or less midpoint with respect to the lifted anthers, which keep apart from it during pollen shed (figs. 3b, c, g, 4e, g).

Opened flowers exhibit differences among the species examined. In $T$. longebracteatus the petals separate only halfway, spread symmetrically and become strongly revolute, and the stamens remain near each other forming a loose tubular fascicle around the style (fig. 4f). In T. secundus the petals and corresponding stamens separate almost completely and spread resulting into a bilateral flower (figs. 3b, g, 4e). The adaxial petal is located on the lower side of the anthetic flower and serves as a platform for the hummingbird beak — videos available upon request-; the stamens and style bend upwards and inwards, which ensures their contact with the hummingbird's head (figs. 1g, 
$3 \mathrm{~b}, \mathrm{c}, \mathrm{g}, 4 \mathrm{e})$. Fully opened flowers are odourless in the two examined species.

Elongation from a $1 \mathrm{~cm}$ to a $11 \mathrm{~cm}$ long corolla tube in T. secundus takes approximately four weeks. Anthesis lasts 14-16 days $-\mathrm{n}=12$ flowers - from the first signs of style protrusion (fig. 3 a, b). Then, petals and attached stamens fall off and within $48 \mathrm{~h}$ the young fruit with the persistent style is apparent (fig. 5n). The style abscisses from its base in the following $48 \mathrm{~h}$ (fig. 5n). By the time the fruit reaches c. $1 \mathrm{~cm}$ in diameter, the green, $3-4 \mathrm{~mm}$ in length embryo has differentiated into a radicle and a plumule, which point towards the proximal and the distal ends of the fruit, respectively (fig. 5p). Morphologically, the leading flower corresponds to the proximal flower of the pendant raceme (figs. 1d, e, h, 3a, b). Approximately five days after opening of the leading flower, the two flowers located immediately below it enter anthesis; this timing is subsequently maintained in the remaining flowers. Fruit set follows the same sequence (figs. 3b, c, 5n). Floral lifespan for $T$. longebracteatus is unknown.

Tristerix secundus is likely pollinated by two hummingbird species, Eriocnemis vestita and Pterophanes cyanopterus (fig. 1g; videos available upon request). Signs of nectar robbers are observed as randomly distributed punctures on the outside of the corolla tube before anthesis, except at the level of the anthers. It is likely that nectar robbers collect the nectar produced by the schizogenous hypodermal cavities of the petals, which are easily accessed from the outside (fig. 4k), compared to the nectar produced directly from the supraovarial nectary ring (figs. $5 \mathrm{j}, \mathrm{k}$ ).

\section{DISCUSSION}

\section{Inflorescence development and structure}

We followed the development of terminal racemes formed by ebracteolate flowers, each subtended by a bract, in the two examined species of Tristerix. The presence of two lateral bracteoles in addition to the subtending bract in flowers of T. aphyllus Tiegh. ex Barlow \& Wiens and T. corymbosus (L.) Kuijt (Reiche 1904; Kuijt 1988) supports the interpretation that each flower along the terminal raceme in $T$. longebracteatus and $T$. secundus corresponds to a dichasium reduced to the terminal flower (Suaza-Gaviria \& al. 2017). However, no evidence of vestigial flowers or bracteoles was found in the species studied here. Interestingly, bracts and bracteoles are formed even in T. aphyllus, a species with extreme reduction of the vegetative organs (Reiche 1904; Mauseth \& al. 1985; Heide-Jørgensen 2008). Racemes are also found in a few New World Loranthaceae, such as a few species of Peristethium Tiegh., but in the latter they are always lateral (Suaza-Gaviria \& al. 2017).
The most conspicuous traits of the inflorescence structure in the Colombian species of Tristerix related to hummingbird pollination are: the horizontal $-T$. secundus - to nearly upright $-T$. longebracteatus position of the many-flowered racemes; the flowers attached to a stout pedicel that could facilitate perching; the sharp angle between the bract and the flower that maintains a suitable position for visits and perching; and the gradual anthesis beginning with the opening of the leading flower, followed by the flowers below it, with time intervals of c. 5 days. Most of these traits have also been reported in other hummingbird pollinated extratropical species of Tristerix (Tadey \& Aizen 2001).

\section{Floral development and structure}

Our results document for the first time the fenestrate and explosive anthesis in T. secundus (fig. 3), and confirm the occurrence of fenestrate corolla opening in T. longebracteatus reported by Amico \& al. (2007). The fenestrate anthesis in Loranthaceae, firstly described in Old World mistletoes by Evans (1895), consists on the opening of lateral window-like slits between petals prior the opening of the corolla tip, comparable to "lighted candles" (Evans 1895: 235) or "Chinese lanterns" (Bernhard \& al. 1980: 441). Among New World genera of Loranthaceae, fenestrate anthesis appears to be restricted to Tristerix; previous accounts are known for T. aphyllus, T. corymbosus, T. longebracteatus, T. peruvianus (Pacz.) Kuijt, and T. pubescens Kuijt (Johow 1900; Kuijt 1988; Amico \& al. 2007). Amico \& al. (2007) postulated that the fenestrate anthesis in some species of the "northern clade" - T. chodatianus (Pacz.) Kuijt, T. grandiflorus (Ruiz \& Pav.) Barlow \& Wiens, T. longebracteatus, T. peytonii Kuijt, T. peruvianus, and T. pubescens-could be a synapomorphy for this clade. However, fenestrate anthesis also occurs at least in two of the four "southern clade" species included in the Amico \& al. (2007) analysis, T. aphyllus and T. corymbosus, and as shown in the present study, in T. secundus. Thus, this trait is a potential synapomorphy for the entire genus.

We also report here for the first time that fenestrate anthesis, at least in $T$. secundus, begins asymmetrically and it is uniquely triggered by the outward tension of the elongating style against the commissure of the two abaxial petals (fig. 3a, d-f), followed by the explosive opening of the corolla tube apex (fig. $3 \mathrm{~g}$ ). The commissure between the two abaxial petals at their midlevel is looser than the remaining four commissures, and offers much less mechanical constraint than the tighly interlocked and twisted petal tips (figs. 3e-g, 4k).

The fenestrate floral opening is frequent among Old World Loranthaceae (cf. Kirkup 1998). There are accounts in species of the Australian Amyema Tiegh. (Blakely 1922; Dixit 1958; Bernhard \& al. 1980), the African 
Erianthemum dregei (Eckl. \& Zeyh.) Tiegh. and Englerina woodfordioides (Schweinf.) Balle ex M.G.Gilbert, the New Zealand Alepis flavida Tiegh., Peraxilla colensoi (Hook.f.) Tiegh., Peraxilla tetrapetala (L.f.) Tiegh., and Trilepidea adamsii Tiegh. (Evans 1895; Feehan 1985; Aluri \& Subba Redi 1995), and the Bornean Amylotheca duthieana (King) Danser (Yumoto \& al. 1997). Fenestrae have also been illustrated in flowers of Agelanthus platyphyllus Hotchst. ex A.Rich. - fig. 72 in Engler \& Krause (1935) - and Helicanthes Danser - figs. 4 and 5 in Johri \& al. (1957)-. In all of these species the fenestrae are caused by the staminal tension against the tip of the corolla tube (Werth 1915; Feehan 1985; Aluri \& Subba Redi 1995; Ladley \& al. 1997; Yumoto \& al. 1997). According to Ladley \& al. (1997), the explosive anthesis syndrome has arisen several times independently within the Loranthaceae, and occurs in some of the early diverging genera. Thus, it is likely that the mechanisms that drive fenestrate and explosive anthesis are different among taxa. Here, we describe for the first time that the first - abaxial - opening of the corolla tube in $T$. secundus is directly triggered by the outwards tension from the elongating style, differing from the stamen-mediated fenestra in Old World taxa.

Fenestrate, explosive anthesis has long been associated to ornithophily, which is the primary pollination mechanism in both Old and New World Loranthaceae (Reiche 1904; Werth 1915; Blakely 1922; Feehan 1985; Galetto \& al. 1990; Kirkup 1998; Aizen 2005). However, this type of anthesis is not limited to cross-pollinated mistletoes, as it can occur also under self-compatibility and even cleistogamy; for example, in the fenestrate flowers of Peraxilla colensoi and Peraxilla tetrapetala the anthers dehisce and pollen is shed during preanthesis (Ladley $\&$ al. 1997). Cleistogamy can be ruled out in the two species of Tristerix examined, as the anthers dehisce after the opening of the corolla tube.

The visits of the likely pollinator hummingbirds Eriocnemis vestita (fig. $1 \mathrm{~g}$ ) and Pterophanes cyanopterus are the first records for $T$. secundus, although experiments are needed to fully demonstrate it. Nectar in flowers of the two examined species of Tristerix is produced by the supraovarial nectary disk, and in the mesophyll of the petals (figs. 4k, 1, 5j-1). Floral orientation in these species differs, as it is upright in $T$. longebracteatus and horizontal in $T$. secundus; however, the floral orientation does not appear to affect the efficiency of hummingbird visits or the volume or concentration of nectar, as demonstrated by Tadey \& Aizen (2001) in T. corymbosus. The production of nectar in the petal mesophyll, reported here for the first time in the genus, is likely related to the visits of floral piercers, detected by frequent punctures on the outside of the petals. Although Graves (1982) — see also Amico \& al. (2007) reported that two flower-piercer species of Diglossa serve as pollinators of T. longebracteatus in northern Peru, it is likely that they are not the primary pollinators of this species as the punctures are made in preanthetic flowers and far below the anthers and the stigma.

Four large orange/yellow/red-flowered lineages from tribe Psittacantheae Horan. - following classification by Nickrent \& al. (2010) - converge in Colombia: Tristerix from subtribe Ligarinae Nickrent \& Vidal-Russell; and Aetanthus, Psittacanthus Mart., and Tripodanthus Tiegh. from subtribe Psittacanthinae Engl. Whereas hummingbird pollination has been observed in Aetanthus and Psittacanthus (fig. 6), this mechanism is likely facultative in Aetanthus mutisii Engl., as cleistogamy seems to occur in this species (Suaza-Gaviria \& al. 2016). No information is available for pollination of the redflowered Tripodanthus belmirensis F.J.Roldán \& Kuijt, the only Colombian species of the genus.

According to Vidal-Russell \& Nickrent (2008), tubular and bird-pollinated flowers evolved independently from insect-pollinated ancestors, once in the clade formed by Tristerix and Ligaria Tiegh., and once in Aetanthus plus Psittacanthus. This is supported by significant flower morphological differences and pollination strategies between them. The population of T. secundus studied for the present research is sympatric with Aetanthus mutisii and individuals of both species grow only a few meters apart and occasionally share the same host individual (fig. 6). Aetanthus mutisii is more abundant and occupies higher strata in the subpáramo vegetation, whereas T. secundus is locally rare and occupies lower strata (fig. 6). Ornithophilous traits related to inflorescence and floral morphoanatomy of $T$. secundus strongly differ from those found in its sympatric Aetanthus mutisii. In T. secundus, the anthesis is fenestrate, explosive, and occurs along the entire length of the corolla tube, the anthers are dorsifixed and tetrasporangiate, the stamens spread away from the style during anthesis, the hummingbird's beak enters in direct contact to the nectary disk as well as the nectar produced in the petals, especially the adaxial one that serves as a platform for the hummingbird's beak. Conversely, the corolla of Aetanthus mutisii is not fenestrate, and it opens only at its distal portion, exposing the baxifixed, polisporangiate anthers, which remain connivent forming a tube around the style; in this species, the hummingbird's beak is far from approaching the nectar disk, and the nectar slides down and accumulates mostly around the base of the connivent anthers (fig. 6; Suaza-Gaviria \& al. 2016). Thus, the site of nectar accumulation allows the short-beaked hummingbird Eriocnemis vestita to easily access it and get dusted with pollen (fig. 6). This contradicts the purported role of long-beaked hummingbirds (cf. Heide-Jørgensen 2008) as pollinators in Aetanthus. 

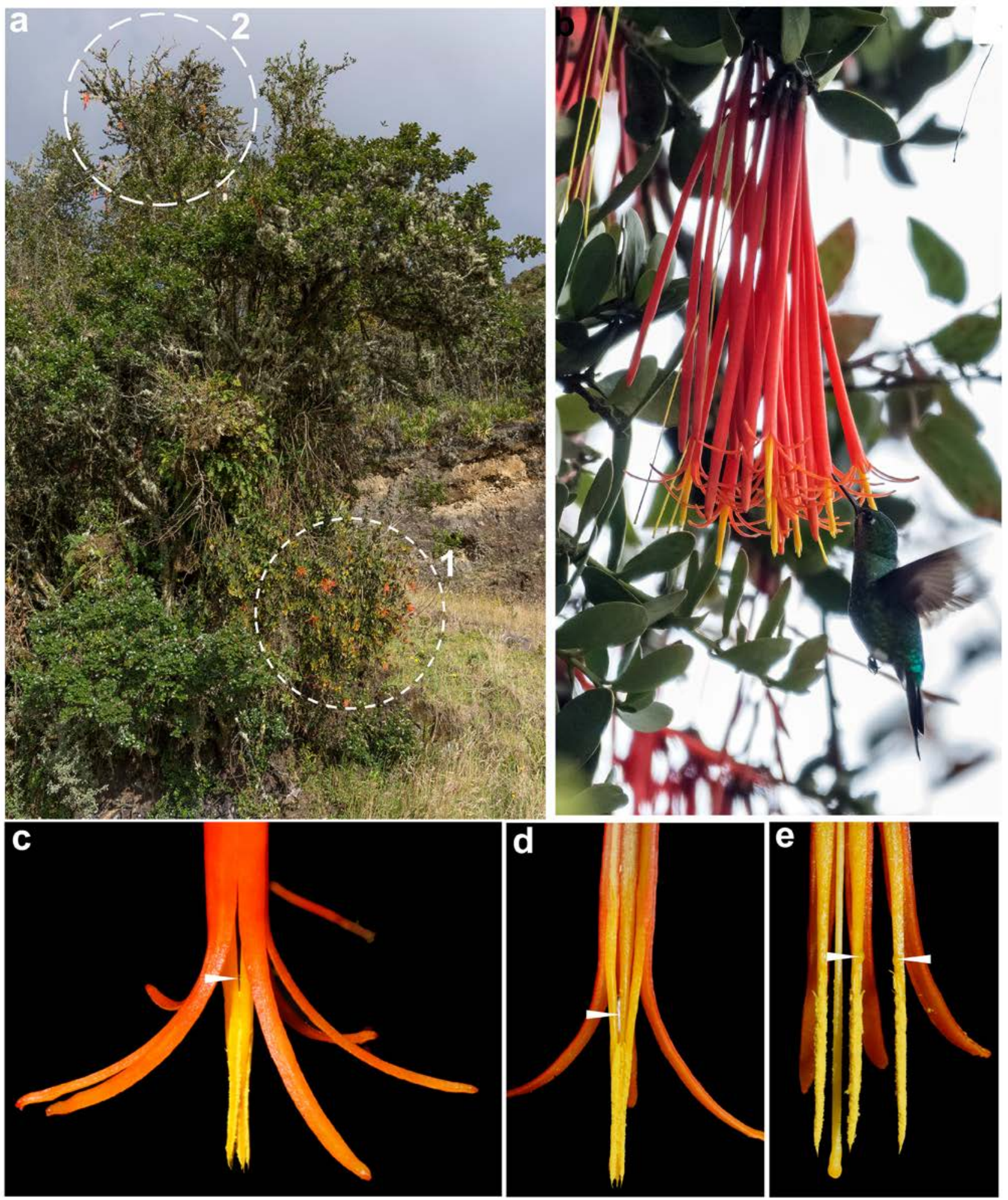

Fig. 6. Ornithophilous traits related to the inflorescences: a, Tristerix secundus (Benth.) Kuijt (1) sharing a host individual of Ageratina baccharoides (Kunth) R.M.King \& H.Rob. with (2) Aetanthus mutisii Engl.; b, short-beaked hummingbird (Eriocnemis vestita) visiting flowers of Aetanthus mutisii; c, outer details of the apex of corolla tube and protruding stamens of Aetanthus mutisii; d, e, inner details of the apex of corolla tube and protruding stamens of Aetanthus mutisii. [Anthers in e have been dissected apart; arrowheads point to nectar acummulation.] 
Table 1. Comparison of morphological traits between Tristerix and its putative sister taxa, Ligaria - according to VidalRussell \& Nickrent (2008) — and Desmaria-Tupeia — according to Wilson \& Calvin (2006)—. Data for Tristerix taken mainly from this study, Kuijt (1988), and Heide-Jørgensen (2008). Other sources: Kuijt (1985, 2015) for Desmaria; Bhatnagar \& Chandra (1968), Galetto \& al. (1990) and Kuijt (2015) for Ligaria; and Van Tieghem (1895), Smart (1952), Ladley \& al. (1997) and Kuijt (2015) for Tupeia.

\begin{tabular}{|c|c|c|c|c|}
\hline Trait & Tristerix & Ligaria & Desmaria & Tupeia \\
\hline Haustorium & single & single & $\begin{array}{l}\text { multiple haustoria in } \\
\text { epicortical roots }\end{array}$ & single \\
\hline Shoots & isomorphic & isomorphic & dimorphic & isomorphic \\
\hline Leaves & $\begin{array}{c}\text { alternate, decussate or } \\
\text { whorled }\end{array}$ & alternate & decussate or whorled & decussate \\
\hline $\begin{array}{l}\text { Cataphylls on renewal } \\
\text { shoots }\end{array}$ & absent & absent & present & present \\
\hline $\begin{array}{l}\text { Inflorescence/partial } \\
\text { inflorescences }\end{array}$ & terminal raceme/1-flower & $\begin{array}{c}\text { Axillary/flowers solitary } \\
\text { or in } 2-3 \text { flowered } \\
\text { fascicles }\end{array}$ & terminal raceme/dichasia & terminal raceme/dichasia \\
\hline Bracts/bracteoles & present/present or absent & present/present & present/present & absent/absent \\
\hline Flowers & bisexual & bisexual & bisexual & $\begin{array}{l}\text { unisexual (dioecious } \\
\text { plants) }\end{array}$ \\
\hline Colour of corolla & bright red, orange, yellow & red, orange, yellow & yellow to red & pale green \\
\hline Anthesis & fenestrate & not fenestrate & not fenestrate & not fenestrate \\
\hline $\begin{array}{l}\text { Corolla and androecium } \\
\text { merosity }\end{array}$ & (4)5 or 6 -merous & hexamerous & hexamerous & tetramerous \\
\hline Corolla & tubular, 3-16 cm long & tubular, 4-6 cm long & tubular, to $3.5 \mathrm{~cm}$ long & stellate, $<4 \mathrm{~mm}$ long \\
\hline Ligule at base of petals & absent & present & absent & absent \\
\hline $\begin{array}{l}\text { Nectar production on petal } \\
\text { mesophyll }\end{array}$ & $\begin{array}{l}\text { present at least in } \\
\text { T. longebracteatus and } \\
\text { T. secundus }\end{array}$ & none & $?$ & $?$ \\
\hline Stamens & $\begin{array}{l}\text { same length to three } \\
\text { different lenghts }\end{array}$ & two different lengths & two different lengths & same length \\
\hline Anthers & dorsifixed, versatile & dorsifixed, versatile & dorsifixed, versatile & basifixed, not versatile \\
\hline Style/stigma & sinuous/capitate, entire & straight/not capitate, entire & straight/not capitate, entire & $\begin{array}{c}\text { straight/capitate, slightly } \\
\text { lobed }\end{array}$ \\
\hline Berry colour & $\begin{array}{l}\text { black, dark red or dark } \\
\text { purple }\end{array}$ & dark blue & $?$ & $\begin{array}{l}\text { whitish to faintly pink, } \\
\text { hyaline }\end{array}$ \\
\hline Cotyledons & equal, distally connate & equal, free & unequal, free & equal, free \\
\hline Pollen vectors & birds & birds & birds & insects \\
\hline Pollen & trilobed & trilobed & trilobed & globose \\
\hline Chromosome number & 12 & 10 & $16 ?$ & 11 \\
\hline Geographic distribution & $\begin{array}{l}\text { Andes from C Colombia } \\
\text { to Chile }\end{array}$ & $\begin{array}{c}\text { C Peru, E Bolivia, Brazil } \\
\text { (Minas Gerais), C Chile, } \\
\text { Uruguay, N Argentina }\end{array}$ & S Chile & New Zealand \\
\hline
\end{tabular}

Systematic and taxonomic significance of inflorescence and floral traits

Phylogenetic relationships of Tristerix are still unresolved and the competing scenarios pose important biogeographic implications. Wilson \& Calvin (2006) stated that the genus is sister to the subclade formed by the monotypic Desmaria Tiegh., from the Andes, and Tupeia Cham. \& Schltdl., from New Zealand. Conversely, VidalRussell \& Nickrent (2008) and Su \& al. (2015) postulated a sister group relationship with the South American Ligaria. A comparison of a number of morphological traits between these four genera is inconclusive (table 1); whereas the lack of protective cataphylls in renewal shoots occurs in Ligaria and Tristerix, the terminal position of the inflorescences occurs in Tristerix, Desmaria, and Tupeia (table 1).

Two generic or specific-level traits that have been used for taxonomic purposes require further examination. The isomorphic stamens described for Tristerix by Barlow \& Wiens (1973) and Kuijt (1988) are not evident in T. secundus, whose flowers have three stamen lengths instead (figs. 2d, e, 4b-e); our study indicates that this trait should be examined throughout floral development. Our results also show that the anthers in the species examined are dorsifixed (fig. 4d, g, h), contrasting Kuijt's (1988) description of Tristerix anthers as basifixed. In addition, the finding of a subterminal gland in the filaments of T. secundus (fig. $4 \mathrm{~d}, \mathrm{~g}$ ) and minute epidermal teeth that 
point backwards in the filaments of $T$. longebracteatus (fig. 4h) suggest that the filament can provide critical and so far overlooked traits for the taxonomy of the genus.

Tristerix longebracteatus and T. secundus belong to the T. subg. Metastachys (Benth.) Kuijt, characterized by the lack of the two lateral bracteoles associated to the floral pedicel (Kuijt 1988). The monophyly of this subgenus was not confirmed in the molecular-based analysis by Amico \& al. (2007), who recovered two geographically centered clades, as follows: The "northern clade", which comprises T. chodatianus (Patsch.) Kuijt, T. grandiflorus (Ruiz \& Pav.) Barlow \& Wiens, T. longebracteatus, T. peytonii Kuijt, T. peruvianus (Patsch.) Kuijt, and T. pubescens Kuijt; and the "southern clade", with T. aphyllus, T. corymbosus, T. penduliflorus Kuijt, and T. verticillatus (Ruiz \& Pav.) Barlow \& Wiens. Although T. secundus was not sampled by Amico \& al. (2007), these authors postulated that it belongs to the "northern clade". Future analyses that include $T$. secundus, will help to asses which floral features reported here are unique to this species and which could be assigned as synapomorphies supporting the putative relationship between $T$. secundus and species of the "northern clade".

\section{ACKNOWLEDGEMENTS}

We thank Frank G. Stiles (Universidad Nacional de Colombia) for the identification of the hummingbird species here reported, and Sebastián González (Universidad Nacional de Colombia) for field assistance and for taking most of the photographs and videos for this research.

\section{REFERENCES}

Aizen M.A. 2005. Breeding system of Tristerix corymbosus (Loranthaceae), a winter-flowering mistletoe from the southern Andes. Australian Journal of Botany 53: 357-361. https://doi.org/10.1071/BT04088

Aluri R.J.S. \& Subba Redi S. 1995. Explosive pollen release and pollination in flowering plants. Proceedings of the Indian National Science Academy B61: 323 332 .

Amico G.C., Vidal-Russell R. \& Nickrent D.L. 2007. Phylogenetic relationships and ecological speciation in the mistletoe Tristerix (Loranthaceae): The influence of pollinators, dispersers, and hosts. American Journal of Botany 94: 558-567. https://doi.org/10.3732/ajb.94.4.558

Barlow B.A. \& Wiens D. 1973. The classification of the generic segregates of Phrygilanthus (= Notanthera) of the Loranthaceae. Brittonia 25: 26-39. https://doi.org/10.2307/2805488

Bernhard P., Knox R.B. \& Calder D.M. 1980. Floral biology and self-incompatibility in some Australian mistletoes of the genus Amyema (Loranthaceae). Australian Journal of Botany 28: 437-451. https://doi.org/10.1071/BT9800437

Bhatnagar S.P. \& Chandra S. 1968. Endosperm in Psittacanthus. Current Science 24: 704-706.

Bhatnagar S.P. \& Johri B.M. 1983. Embryology of the Loranthaceae. In Calder M. \& Bernhardt P. (eds.), The biology of mistletoes: 47-67. Academic Press, Sydney.

Blakely W.F. 1922. The Loranthaceae of Australia. Proceedings of the Linnean Society of New South Wales 47: 1-25.

Dixit S.N. 1958. Morphological and embryological studies in the family Loranthaceae IV. Amyema van Tiegh. Phytomorphology 8: 346-364.

Engler A \& Krause K. 1935. Loranthaceae. In Engler A. \& Prantl K. (eds.), Die Natürlichen Pflanzenfamilien ed. 2: 98-203. Engelmann, Leipzig.
Evans M.S. 1895. The fertilisation of Loranthus kraussianus and L. dregei. Nature 51: 235-236. https://doi.org/10.1038/051235a0

Feehan J. 1985. Explosive flower opening in ornithophily: a study of pollination mechanisms in some Central African Loranthaceae. Botanical Journal of the Linnean Society 90: 129-144. https://doi.org/10.1111/j.1095-8339.1985.tb02205.x

Galetto L., Bernardello L. \& Juliani H.R. 1990. Acerca del nectario, néctar y visitantes florales en Ligaria cuneifolia (Loranthaceae). Darwiniana 30: 155-161. http://www.jstor.org/stable/23222525

Graves G.R. 1982. Pollination of a Tristerix mistletoe (Loranthaceae) by Diglossa (Aves, Thraupidae). Biotropica 14: 316-317. https://doi.org/10.2307/2388094

Heide-Jørgensen H.S. 2008. Parasitic flowering plants. Brill, Leiden, Netherlands. https://doi.org/10.1163/ej.9789004167506.i-438

Johow F. 1900. Zur Bestäubungsbiologie chilenischer Blüthen. I. Verhandlungen des Deutschen wissenschäflichen vereins zu Santiago de Chile 4: 1-22.

Johri B.M., Agrawal J.S. \& Garg S. 1957. Morphological and embryological studies in the family Loranthaceae. I. Helicanthes elastica (Desr.) Dans. Phytomorphology 7: $336-354$.

Kirkup D. 1998. Pollination mechanisms in African Loranthaceae. In Polhill R \& Wiens D. (eds.), Mistletoes of Africa: 37-60. Royal Botanic Gardens, Kew.

Kuijt J. 1985. Morphology, biology, and systematic relationships of Desmaria (Loranthaceae). Plant Systematics and Evolution 151: 121-130. https://doi.org/10.1007/BF02418024

Kuijt J. 1988. Revision of Tristerix (Loranthaceae). Systematic Botany Monographs 19: 1-61. https://doi.org/10.2307/25027693

Kuijt J. 2015. Santalales. In Kuijt J. \& Hansen B. (eds.), The families and genera of vascular plants 12: 1-189. Springer, Cham.

Ladley J.J., Kelly D. \& Robertson A.W. 1997. Explosive flowering, nectar production, breeding systems, and pollinators of New Zealand mistletoes (Loranthaceae). New Zealand Journal of Botany 35: 345-360. https://doi.org/10.1080/0028825X.1997.10410160

Maheshwari P., Johri B.M. \& Dixit S.N. 1957. The floral morphology and embryology of the Loranthoideae (Loranthaceae). Journal of the Madras University 27: 121-136.

Mauseth J.D., Montenegro G. \& Walckowiak A.M. 1985. Host infection and flower formation by the parasite Tristerix aphyllus (Loranthaceae). Canadian Journal of Botany 63: 567-581. https://doi.org/10.1139/b85-072

Nickrent D.L., Malécot V., Vidal-Russell R. \& Der J.P. 2010. A revised classification of Santalales. Taxon 59: 538-558.

Reiche K. 1904. Bau und Leben der chilenischen Loranthacee Phrygilanthus aphyllus. Flora 93: 271-297.

Smart C. 1952. The life history of Tupeia Cham. et Schl. (Loranthaceae). Transactions of the Royal Society of New Zealand 79: 459-466.

Su H-J., Hu J-M., Anderson F.E., Der J.P. \& Nickrent D.L. 2015. Phylogenetic relationships of Santalales with insights into the origins of holoparasitic Balanophoraceae. Taxon 64: 491-506. https://doi.org/10.12705/643.2

Suaza-Gaviria V, Pabón-Mora N.L. \& González F. 2016. Development and morphology of flowers in Loranthaceae. International Journal of Plant Sciences 177: 559-578. https://doi.org/10.1086/687280

Suaza-Gaviria V., González F. \& Pabón-Mora N.L. 2017. Comparative inflorescence development in selected Santalaes. American Journal of Botany 104: 24-38. https://doi.org/10.3732/ajb.1600253

Tadey M. \& Aizen M.A. 2001. Why do flowers of a hummingbirdpollinated mistletoe face down? Functional Ecology 15: 782-790. https://doi.org/10.1046/j.0269-8463.2001.00580.x

Van Tieghem P. 1895. Sur la structure et les affinités des Tupeia, Ginalloa, Phoradendron et Dendrophthora, de la famille des Loranthacees. Bulletin de la Société Botanique de France 42: 643-652. https://doi.org/10.1080/00378941.1895.10830650

Vidal-Russell R. \& Nickrent D.L. 2008. Evolutionary relationships in the showy mistletoe family (Loranthaceae). American Journal of Botany 95: 1015-1029. https://doi.org/10.3732/ajb.0800085 
Werth E. 1915. Kurzer Überblick über die Gesamtfrage der Ornithophilie. Botanische Jahrbücher für Systematik, Pflanzengeschichte und Pflanzengeographie 53: 314-378.

Wilson C.A. \& Calvin C.L. 2006. Character divergences and convergences in canopy-dwelling Loranthaceae. Botanical Journal of the Linnean Society 150: 101-113. https://doi.org/10.1111/j.1095-8339.2006.00488.x
Yumoto T., Itino T. \& Nagamasu H. 1997. Pollination of hemiparasites (Loranthaceae) by the spider hunters (Nectariniidae) in the canopy of a Bornean tropical rain forest. Selbyana 18: 51-60. http://www.jstor.org/stable/41759942 